\title{
PERSPEKTYWY ROZWOJU T€UMACZENIA MASZYNOWEGO (NA PRZYKŁADZIE ANGIELSKO-ROSYJSKICH RELACJI PRZEKŁADOWYCH)
}

\author{
PERSPECTIVES ON THE DEVELOPMENT OF MACHINE TRANSLATION \\ (AS EXEMPLIFIED BY ENGLISH-RUSSIAN TRANSLATION RELATIONS)
}

\section{JAKUB OLAS}

\begin{abstract}
Machine translation (MT) is a relatively new field of science. MT systems are evolving in certain directions. The article discusses the possibilities and the future of systems currently offered to public by the biggest technological companies focusing on English-Russian translation relations.
\end{abstract}

Keywords: machine translation, neural networks, statistical machine translation, neural machine translation

Jakub Olas, Uniwersytet Szczeciński, Szczecin - Polska, jakub.olas@gmail.com

ORCID ID: 0000-0002-2596-1137

Siedemnastowieczna idea wykorzystania maszyn w procesie przekładu języków naturalnych stała się rzeczywistością dopiero $w$ drugiej połowie XX wieku. Programy komputerowe wykonują dziś tłumaczenia na masową skalę i choć nadal z oczywistych względów nie mogą być wykorzystywane do efektywnego odzwierciedlania w przekładzie niuansów znaczenia w tekstach literackich i poezji, to stanowią odpowiedź na wciąż rosnące zapotrzebowanie rynku na szybkie (najlepiej natychmiastowe) i tanie (najlepiej darmowe) tłumaczenia tekstów użytkowych i internetowych. Rozwój systemów tłumaczenia komputerowego opiera się właśnie na tych dwóch filarach - szeroko rozumianym ograniczaniu kosztów (włączając $\mathrm{w}$ to kwestię obniżania czasochłonności samego procesu) przy jednoczesnym osiąganiu jak najwyższej jakości produktu.

Zautomatyzowane tłumaczenie komputerowe, nazywane tłumaczeniem maszynowym (ang. machine translation - MT), od tłumaczenia wspomaganego komputerowo odróżnia głównie stopień zaangażowania człowieka w proces przekładu - w przypadku tego pierwszego przebiega on całkowicie pod kontrolą komputera, w przypadku tego drugiego zaś maszyna jest jedynie narzędziem, a żywy tłumacz bierze odpowiedzialność za decyzje dotyczące wyboru podsuniętych mu rozwiązań [Bogucki 2009: 26-27]. Choć właściwym 
celem systemów komputerowych jest dostarczenie tłumaczenia wysokiej jakości, to z punktu widzenia profesjonalnego tłumacza w praktyce niemal każdy tekst wygenerowany przez maszynę wymaga postedycji lub przynajmniej weryfikacji przez żywego tłumacza. W latach 80. i 90. celem takiej postedycji było doprowadzenie tłumaczenia komputerowego do stanu przynajmniej podstawowej zrozumiałości. Nasuwało to wątpliwości co do sensu wykorzystywania tego typu technologii, ponieważ według niektórych pełna korekta produktu wymagała więcej wysiłku niż bezpośrednie tłumaczenie tekstu źródłowego [Cronin 2016: 166]. Warto zaznaczyć, że w aspekcie postedycji tłumaczenie wykonane przez komputer nie odróżnia się zasadniczo od tradycyjnego tłumaczenia wykonywanego przez człowieka - ostatecznie i w tym drugim przypadku przed oddaniem tekstu potrzebne jest naniesienie poprawek przez korektora lub przynajmniej upewnienie się, że tłumacz nigdzie się nie pomylił. Dość oczywistą kwestią jest fakt, że typy błędów popełnianych przez maszynę różnią się od ludzkich (w przypadku maszyny będą to raczej nieprawidłowe przyimki, rodzajniki, zaimki, czasy gramatyczne itp. niż na przykład błędy ortograficzne lub literówki). Niemniej jednak zdarzają się sytuacje, w których tekst wyprodukowany przez komputer jest dostatecznie dobry (lub wymaga jedynie naniesienia naprawdę niewielkich poprawek), by być wersją ostateczną, jeśli np. jest przeznaczony dla specjalistów w danej dziedzinie. Najczęściej jednak produkt tłumaczenia komputerowego nadal służy tłumaczowi jedynie jako wstępna wersja tekstu docelowego.

Podwaliny pod tłumaczenie komputerowe położył bez wątpienia Warren Weaver, który w lipcu 1949 roku na zlecenie fundacji Rockefellera stworzył powszechnie uznawane za kamień milowy w rozwoju technologii tłumaczeniowych memorandum. Dokument ten zawierał cztery możliwe rozwiązania problemów, na które napotykało tłumaczenie maszynowe na ówczesnym etapie rozwoju, a także prognozy wykorzystania technologii tłumaczenia maszynowego: posłużenie się kontekstem do pokonania problemu wieloznaczności, skorzystanie $\mathrm{z}$ istniejących logicznych powiązań $\mathrm{w}$ ramach systemu języka, wykorzystanie metod kryptograficznych (porównanie przekładu do procesu łamania szyfru) oraz założenie istnienia językowych uniwersaliów [Bogucki 2009: 39].

Niecałe pięć lat później, 8 stycznia 1954 roku, największe amerykańskie gazety, takie jak "New York Times” czy „Washington Herald Tribune”, na swoich pierwszych stronach zamieściły informację na temat pokazu, który odbył się dzień wcześniej w nowojorskiej siedzibie IBM. Nagłówki brzmiały sensacyjnie: Mózg elektronowy ttumaczy z rosyjskiego czy też Robotyczny mózg tłumaczy rosyjski na królewską angielszczyznę i trudno się dziwić entuzjazmowi prasy - było to chyba pierwsze zastosowanie komputera do zadań, które nie wiązały się jedynie z obliczeniami, a biorąc pod uwagę fakt, że sama sztuka 
przekładu nie była zbyt dobrze znana ówczesnym czytelnikom, perspektywa zastosowania maszyny do rozszyfrowywania tekstów w obcych językach musiała wydawać się ekscytująca. System, którego słownik składał się z zaledwie 250 słów, przetłumaczył z rosyjskiego na angielski ponad 60 zdań, pośród których znajdowały się m.in.: Качестbо угля определяется калорийностью - The quality of coal is determined by calory content, Мы передаем мысли посредством речи - We transmit thoughts by means of speech, Дороги строятся из бетона - Roads are constructed from concrete, czy też Военный суд приговорил сержанта к лишению гражданских прав - A military court sentenced a sergeant to deprival of civil rights. Wybór języka rosyjskiego był zapewne motywowany zimnowojenną atmosferą (w końcu nic tak nie przyspiesza rozwoju technologii, jak zainteresowanie ze strony armii), ale nie zmienia to faktu, że to właśnie przekład z języka Puszkina na dobre zapoczątkował erę tłumaczenia maszynowego [Hutchins 2006].

Pionierskie systemy, jak ten zaprezentowany przez IBM, powstawały w czasach, w których moce obliczeniowe komputerów była nieporównywalnie mniejsze niż obecnie, stąd też cechowały je prostota i duża zawodność. Dostarczony materiał wyjściowy poddawany był analizie morfologicznej, określeniu części mowy, weryfikacji ekwiwalentów w dwujęzycznym słowniku systemowym i sformowaniu tekstu docelowego z wykorzystaniem prostych zabiegów, jak przestawienie szyku zdania z pominięciem analizy syntaktycznej czy semantycznej. Ze względu na zastosowane strategie i działania systemy te nazwano bezpośrednimi. Kontekst, fundamentalny dla przekładu, w ich przypadku był całkowicie ignorowany. Dwujęzyczne słowniki systemowe tworzono w sposób, który maksymalnie redukował problem homonimii, a zatem zawężając ich zawartość do podstawowych znaczeń słów [Bogucki 2009: 29-30]. System wykonywał więc czynności umożliwiające jedynie sprowadzenie wyrazu do formy podstawowej i odnalezienie go w słowniku identyfikował część mowy, czas gramatyczny, liczbę etc. Słowniki bilingwalne (siłą rzeczy dla każdej pary językowej należało stworzyć osobny słownik) były w związku z tym kluczowym elementem systemów bezpośrednich i tak naprawdę to od ich jakości zależała jakość finalnego produktu. Aby osiągnąć akceptowalny dla użytkownika efekt, mechanizm działania musiał się opierać na składniowych i semantycznych podobieństwach między językiem wyjściowym a docelowym (większa liczba podobieństw równała się w tym wypadku wyższej jakości produktu końcowego). Niestety szczątkowość informacji wprowadzanych do tego rodzaju systemów sprawiała, że wytworzone przy ich wykorzystaniu tłumaczenia często były bardzo kiepskiej jakości, a wręcz nie nadawały się do użytku [Austermühl 2014: 159].

Nowocześniejsze systemy tłumaczenia maszynowego nazwano pośrednimi i można je podzielić przede wszystkim na dwie kategorie: systemy 
oparte na wiedzy oraz systemy oparte na danych. Pierwsze z wymienionych to algorytmy oparte na regułach językowych (ang. rule-based machine translation - RBMT), które (w dużym uproszczeniu) wykonują analizę tekstu źródłowego, by następnie wygenerować jego pośrednią, symboliczną reprezentację, która służy za podstawę dla utworzenia tekstu docelowego. Efektywność tego rodzaju systemów uzależniona jest w dużej mierze od dostępności obszernych otagowanych leksykonów, zawierających informacje morfologiczne, syntaktyczne i semantyczne oraz rozbudowane zestawy reguł gramatycznych, opartych na wyspecjalizowanej wiedzy lingwistycznej. Przykładem systemu RBMT jest system stworzony przez założoną w 1991 roku w Sankt Petersburgu firmę PROMT. System ten ewoluował (choć do tej pory PROMT oferuje oprogramowanie w wersji RBMT) i od 2010 roku najważniejszym produktem rosyjskiej firmy jest hybryda łącząca tłumaczenie oparte na regułach z tłumaczeniem opartym na danych. W latach 2013-2014 system PROMT dwukrotnie zdobył nagrodę Association for Computational Linguistics dla najlepszego systemu tłumaczenia maszynowego dla pary rosyjski - angielski [Bojar et al. 2014].

Metodę tłumaczenia opartego na danych można natomiast określić jako statystyczne tłumaczenie maszynowe (ang. statistical machine translation SMT). Początki SMT sięgają lat osiemdziesiątych XX wieku, kiedy to wraz ze wzrostem mocy obliczeniowych komputerów zyskiwać na znaczeniu zaczęły modele statystyczne tworzone na podstawie analizy dwujęzycznych lub paralelnych korpusów tekstów. Zauważono, że przy pewnej ilości danych statystyczne tłumaczenie maszynowe dość często jest w stanie oddać przybliżone znaczenie tekstu źródłowego. Systemy oparte na regułach zachowują pewną przewagę w zakresie gramatyczności (tłumaczenie oparte na danych częściej generuje teksty niegramatyczne), niemniej jednak to systemy oparte na metodzie statystycznej są $\mathrm{w}$ stanie poprawnie przetłumaczyć fragmenty wynikające z indywidualnych cech danego języka, z którymi system oparty na regułach miałby problem, np. wyrażenia idiomatyczne [Rehm, Uszkoreit 2012: 24-25]. System oparty na danych ma zatem niewątpliwe zalety - $z$ łatwością przyswaja rzadko spotykane słowa oraz frazy i jeśli wystąpiły one w tekstach równoległych, to zapamięta je i w przyszłości będzie je tłumaczyć poprawnie. $\mathrm{Z}$ drugiej strony tłumaczenie wykonane przez taki system przypomina puzzle - ogólny obraz wydaje się być zrozumiały, jednak gdy przyjrzeć się mu z bliska, można dostrzec, że składa się on z kawałków.

Przykładem aktualnie funkcjonującego systemu wykorzystującego przekład statystyczny jest Yandex.Translate (ros. Яндекс.Переводиик), który został zaprezentowany przez rosyjskiego giganta technologicznego w 2011 roku i w tamtym czasie obsługiwał zaledwie 3 języki - rosyjski, angielski i ukraiński. W październiku 2017 roku liczba obsługiwanych przez Yandex. 
Translate języków wyniosła 94. Wykorzystywana przez Yandex.Translate technologia SMT opiera się na porównywaniu setek tysięcy tekstów równoległych (zawierających te same informacje w różnych językach), takich jak dłuższe teksty zamieszczone na stronach internetowych różnych organizacji. Program początkowo wyszukuje teksty równoległe, wykorzystując adresy dokumentów - najczęściej poszczególne wersje językowe wyróżnione są tagami w adresie, takimi jak „en” lub „us” dla języka angielskiego, czy też „pl” lub „ru” dla języka polskiego lub rosyjskiego. Dla każdego zbadanego tekstu system tworzy listę unikalnych cech - mogą to być np. rzadko wykorzystywane słowa, liczby, znaki specjalne rozmieszczone w tekście w określonej kolejności. Kiedy system zbierze dostateczną liczbę tekstów posiadających pewne cechy, rozpoczyna poszukiwania tekstów równoległych z ich pomocą, porównując cechy nowych tekstów z zebranym dotychczas materiałem. Aby zrozumieć ogrom tego przedsięwzięcia należy uświadomić sobie, że w celu zapewnienia akceptowalnej jakości tłumaczenia wypowiedzi o tematyce ogólnej system musi przebadać setki milionów tekstów w różnych językach. System składa się z trzech elementów - tabeli fraz, modelu języka i dekodera. W tabeli fraz, dla każdej językowej pary, wszystkim znanym systemowi słowom i wyrażeniom w jednym języku przypisane są wszystkie możliwe tłumaczenia na język obcy wraz ze wskazaniem trafności przekładu. Tabela ta tworzona jest $w$ trzyetapowym procesie treningu: najpierw gromadzone są teksty równoległe, następnie teksty są dzielone na równoległe segmenty, by na końcu wydzielone zostały pary słów i wyrażeń. Drugim z elementów składających się na system jest model języka. W celu jego utworzenia system bada setki tysięcy najróżniejszych tekstów w danym języku i zestawia listę wszystkich wykorzystanych w nich słów i połączeń wyrazowych ze wskazaniem częstotliwości ich występowania. Można zatem powiedzieć, że stanowi on wiedzę systemu na temat języka, na który będzie przekładany tekst. Tłumaczenie wykonywane jest bezpośrednio przez dekoder. Dla każdego zdania tekstu źródłowego dekoder dobiera wszystkie warianty tłumaczenia, łącząc ze sobą wyrażenia z tabeli fraz, i sortuje je malejąco pod względem trafności. Wszystkie otrzymane warianty połączeń są oceniane przez dekoder za pomocą modelu języka - ostatecznie wybrany zostanie wariant o najwyższej trafności oraz częstotliwości użycia [Bartnicka, Hofmann-Delbor 2017: 149-155].

W dniu 14 września 2017 roku Yandex podłączył do swojego systemu sieć neuronową (ang. neural machine translation - NMT), czyniąc go tym samym systemem hybrydowym. Wprawdzie Yandex.Translate pozwala skorzystać $\mathrm{z}$ najnowszej technologii jedynie $\mathrm{w}$ przypadku języka rosyjskiego i angielskiego, niemniej jednak, dzięki jej zastosowaniu, rosyjska firma dołącza do reszty technologicznych gigantów, oferujących ogólnodostępne translatory 
- tłumaczenie maszynowe oparte na sieciach neuronowych dostarczają już bowiem Google, Microsoft, a także chińska korporacja Baidu [Yandex 2017].

W dużym uproszczeniu działanie NMT opiera się na efektach treningu sieci neuronowej (system wymaga bowiem treningu podobnie, jak w przypadku technologii SMT, choć należy zaznaczyć, że w przypadku NMT trwa on kilkukrotnie dłużej), czyli analizy ogromnej liczby tekstów równoległych oraz nadawania wagi poszczególnym elementom decyzyjnym sieci. Tłumaczenie odbywa się dzięki temu, że każde słowo zostaje zakodowane przy użyciu setek parametrów, reprezentujących jego unikalne charakterystyki w ramach danej językowej pary (np. angielskiego i mandaryńskiego - pierwszej pary, dla której Google udostępnił NMT). Bazując na parze językowej wykorzystanej do treningu, sieć neuronowa sama określa, jakie to powinny być parametry. Mogą zostać w nich zakodowane proste informacje, jak rodzaj (męski, żeński, nijaki), rejestr (żargon, potoczny, książkowy, oficjalno-urzędowy etc.), określenie jaką częścią mowy jest dane słowo itp., ale także jakakolwiek inna nieoczywista charakterystyka wywnioskowana na podstawie danych treningowych. Każde słowo, a ściślej rzecz ujmując, reprezentująca je lista parametrów jest przepuszczana przez pierwszą warstwę sieci neuronowej, która ponownie koduje je do kolejnej listy setek parametrów reprezentującej słowo w określonym kontekście pozostałych słów występujących w zdaniu. Gdy wszystkie słowa zostaną w ten sposób zakodowane, zostają przepuszczone do kolejnej warstwy sieci, gdzie proces się powtórzy (w przypadku systemu NMT opisywanego w dokumentacji Google zastosowano 8 warstw, przez które przepuszczany zostaje tekst źródłowy). Każda kolejna warstwa sieci ma za zadanie dopracować macierz parametrów reprezentujących wyraz w kontekście całego zdania (w przypadku systemów opartych na statystykach możliwa była analiza od 3 do 5 słów jednocześnie). Ostatnia, wyjściowa macierz jest wykorzystywana przez algorytm, który użyje zarówno jej, jak i poprzednio przetłumaczonych słów do określenia, które słowo ze zdania źródłowego powinno zostać przetłumaczone jako następne. Algorytm wykonuje również analizę, która w razie potrzeby pozwoli pominąć zbędne słowa w języku docelowym. W ostatnim etapie procesu warstwa tłumaczeniowa sieci (dekoder) przekłada wybrane słowo (a raczej jego reprezentację) na najbardziej trafny ekwiwalent w języku docelowym (tekst docelowy, podobnie jak źródłowy, również zostaje przepuszczony przez 8 warstw sieci, by system był w stanie dobrać ekwiwalent w możliwie najtrafniejszy sposób, ograniczając się jedynie do analizy parametrów) [Wu et al. 2016].

Systemy oparte na sieciach neuronowych są w tej chwili najbardziej zaawansowane, niemniej jednak ich zastosowanie wymaga $\mathrm{z}$ reguły ogromnych mocy obliczeniowych i relatywnie dużej ilości czasu poświęconego na trening (kilkukrotnie większej niż w przypadku systemów tłumaczenia opartego na 
danych). Oprócz tego systemy NMT słabo radzą sobie z rzadko spotykanymi słowami, które nie stanowiły problemu dla systemów SMT, zdarza im się również pomijać niektóre słowa w tłumaczeniu na język docelowy. Systemy SMT nadal radzą sobie lepiej także z tłumaczeniem dłuższych zdań (im dłuższe zdanie, tym wyraźniejsza przewaga SMT, choć należy pamiętać, że wynika to $z$ tego, że w przeciwieństwie do NMT, SMT nie bierze pod uwagę zdania całościowo). Niemniej jednak, dzięki analizie całych zdań, tłumaczenia wykonane przez NMT zdecydowanie bardziej przypominają te wykonywane przez człowieka i od pewnego czasu zdecydowanie lepiej wypadają zarówno w testach zautomatyzowanych, jak i w ocenie człowieka [Popović 2017].

O różnicach między tłumaczeniem statystycznym a opartym na sieciach neuronowych można przekonać się samemu na stronie Microsoft Translato$\mathrm{ra}^{1}$, na której przetłumaczony tekst wyświetlany jest $\mathrm{w}$ dwóch okienkach po wybraniu przez użytkownika bardziej poprawnej według niego wersji, otrzymuje on informację o tym, która $z$ nich została wygenerowana przez sieć neuronową, a która przez starszą, statystyczną wersję systemu. Wśród dwunastu języków, dla których Microsoft udostępnia tłumaczenie w oparciu o sieci neuronowe znajduje się język rosyjski.

Obecność języka rosyjskiego w największych ogólnodostępnych systemach tłumaczenia komputerowego ma w dzisiejszych czasach nieco inny charakter niż kilkadziesiąt lat temu. Pomimo skomplikowanej sytuacji politycznej w regionie raczej nie możemy mówić o nowej zimnej wojnie i wyścigu zbrojeń, który wymuszałby na mocarstwach podejmowanie prób automatyzowania tłumaczeń dla celów wojskowych. Zimnowojenną rolę języka rosyjskiego przejęły języki azjatyckie - mandaryński (w związku z chińsko-amerykańskim wyścigiem gospodarczo-technologicznym - być może to właśnie dlatego Google uruchomił technologię NMT w pierwszej kolejności dla pary angielski - mandaryński) oraz arabski (ze względu na militarne zaangażowanie Stanów Zjednoczonych w konflikty na Bliskim Wschodzie). Skąd zatem zainteresowanie amerykańskich gigantów technologicznych tym językiem? To oczywiste, że w związku z tym, że jest on najliczniej reprezentowanym spośród języków słowiańskich zasługuje na szczególną uwagę, niemniej jednak równorzędne znaczenie w tym wypadku może mieć to, że Rosjanie też mają swojego giganta w postaci firmy Yandex. Kluczem do sukcesu w branży technologicznej jest szybkość - na rynku mogą zaistnieć tylko ci gracze, którzy zaproponują swoje rozwiązania jako pierwsi (lub przynajmniej jako jedni z pierwszych) - ograniczenie dostępu do grupy użytkowników złożonej z ponad 200 milionów osób posługujących się językiem rosyjskim (jak w przypadku serwisu Facebook, który przez długi czas nie oferował rosyjskiej wersji

${ }^{1}$ translator.microsoft.com/neural 
językowej i w efekcie przegrał rywalizację o rosyjskojęzycznych internautów z serwisem vk.com) byłoby działaniem nierozsądnym.

Przypadek języka rosyjskiego (choć dotyczy to właściwie ogółu języków słowiańskich), mającego bogatą morfologię i swobodny szyk zdania, dobitnie unaocznia fakt, że przynajmniej na razie potencjał profesjonalnego zastosowania tłumaczenia komputerowego ogranicza się głównie do tekstów technicznych oraz tekstów, których odbiorcom nie zależy na wysokiej jakości wygenerowanego produktu (nie ma mowy o wykorzystaniu technologii MT do tłumaczenia tekstów literackich, jednak tłumaczenia np. tekstów marketingowych niewymagających czasochłonnej postedycji tymczasem również leżą poza zasięgiem komputerów). Nietrudno jednak zauważyć tendencję do integracji systemów tłumaczenia maszynowego z innymi programami i aplikacjami. Facebook tłumaczy automatycznie wpisy użytkowników; Google w swojej przeglądarce Chrome daje użytkownikom możliwość tłumaczenia całych stron internetowych za pośrednictwem kilku kliknięć, w swojej poczcie elektronicznej, Gmail, otrzymanej korespondencji w języku obcym, a aplikacja Google Translate na smartfony w połączeniu z Word Lens może tłumaczyć otaczające nas napisy, wykorzystując do tego kamerę telefonu; Microsoft idzie nawet o krok dalej - oprócz dodatku do przeglądarki Edge (tłumaczenie stron internetowych) oraz do programu Outlook (tłumaczenie korespondencji elektronicznej), umożliwia też tłumaczenie mowy na tekst w innym języku w czasie rzeczywistym w komunikatorze Skype. Skype Translator jest o tyle ciekawym systemem, że łączy w sobie kilka różnych systemów - moduł rozpoznawania mowy sprowadza najpierw ustną wypowiedź do formy zapisu, by otrzymany $w$ ten sposób tekst przesłać do silnika systemu tłumaczenia komputerowego. Co więcej, otrzymany tą drogą tekst może zostać ostatecznie odczytany przez moduł text-to-speech, który naśladuje ludzki głos [Bartnicka, Hofmann-Delbor 2017: 144-145]. Powoli na rynek wprowadzana jest także aplikacja, która umożliwia wyświetlanie przetłumaczonych w czasie rzeczywistym napisów podczas prezentacji z wykorzystaniem programu PowerPoint. Firma SDL, producent oprogramowania typu CAT (ang. computer assisted translation - tłumaczenie wspomagane komputerowo), zaprezentowała natomiast aplikację AdaptiveMT, która pozwala wytrenować system tłumaczenia maszynowego z wykorzystaniem tłumaczeń wykonanych wcześniej, co ma na celu nauczenie programu stylu danego użytkownika [Ferguson 2016].

Dążenie do poprawy jakości produktu tłumaczenia komputerowego, oprócz stosowania coraz bardziej zaawansowanych technologii, przejawia się także poprzez narzucanie restrykcyjnych warunków, jakie powinien spełniać tekst źródłowy. System MT może zostać zaprojektowany np. do tłumaczenia tekstów ograniczających się do języka tylko jednej dziedziny lub określonego typu dokumentów (np. patentów). Szczególne zastosowanie w tego typu 
przypadkach znajdują więc różne wersje kontrolowanych języków naturalnych (ang. controlled natural languages - CNL), pozwalające uniknąć niespójności lub nadmiernej kreatywności, która generując tzw. przypadkowe treści, generuje dodatkowe koszty (ostatecznie im więcej powiemy w jednym języku, tym więcej kosztuje powiedzenie tego w innych językach). Angielskie CNL zazwyczaj cechują specyficzne zasady gramatyczne i stylistyczne: słownictwo jest ograniczone, wybrane w sposób dążący do wyeliminowania wieloznaczności, zdania są zwięzłe, czasowniki występują raczej w stronie czynnej niż biernej. Standaryzowane teksty w ogóle są zdecydowanie łatwiejsze do tłumaczenia, a ich przekłady można często wykorzystać ponownie - ryzyko powstania „przypadkowych treści” jest bowiem niewielkie [Cronin 2016: 53-54]. Wszelkiego rodzaju instrukcje postępowania, zawierające ostrzeżenia, uwagi czy też wielokrotnie użyte części składowe, z łatwością poddają się podmienianiu treści, potwierdzając tym samym teoretyczne przesłanki dotyczące powtarzalności i proceduralności tekstów, leżące u podstaw idei przekładu maszynowego. Kontrolowane języki naturalne natomiast zdają się być logicznym następstwem dążenia do standaryzacji na poziomie jeszcze głębszym niż dotychczas. Najbardziej znanym przykładem wykorzystania systemu tłumaczenia maszynowego do pracy na języku kontrolowanym jest bez wątpienia METEO. Ten kanadyjski system tłumaczenia prognoz pogody z języka angielskiego na francuski funkcjonował przez 30 lat od roku 1981 i był swego czasu jednym z nielicznych dowodów na to, że technologie MT można zastosować z sukcesem. Zapotrzebowanie na automatyczny system tłumaczący prognozy pogody wynikało nie tylko z dwujęzyczności Kanady, ale również z faktu braku zainteresowania profesjonalnych tłumaczy pracą nad prognozami pogody, która uchodziła za monotonną, nieciekawą i była słabo opłacana. Poruszanie się w obszarze języka kontrolowanego, ściśle ustalony format tekstu i pewne stałe jego elementy sprawiały, że system uzyskiwał bardzo wysoką, a niejednokrotnie nawet stuprocentową dokładność, pomimo specyfiki języka francuskiego, która w innym wypadku mogłaby przysparzać systemowi problemów w zakresie analizy morfologicznej [Bogucki 2009: 44].

Pomysłowość w dążeniu do minimalizacji kosztów nie zna jednak granic - wśród poszukujących oszczędności pojawiają się dość absurdalne postulaty, jak na przykład narzucenie lingua franca. Krytycy wielojęzyczności instytucji ponadnarodowych, takich jak Unia Europejska, twierdzą, że gdyby jedynym jej językiem roboczym był wspólny język, np. angielski, można by zaoszczędzić znaczne sumy wydawane na tłumaczenia pisemne i ustne. Dowodzenie, że wykorzystanie lingua franca wyeliminuje koszty przekładu dotyczy w rzeczywistości ich przesunięcia - zanim możliwe będzie wejście $\mathrm{w}$ rolę potencjalnych odbiorców lub nadawców lingua franca, niezbędne będzie jej 
przyswojenie, nierzadko generujące znaczne koszty. Argument o minimalizowaniu kosztów przewija się niezwykle często w kontekście tłumaczenia maszynowego, niemniej jednak warto zwrócić uwagę na fakt pomijania rzeczywistego znaczenia pojęcia kosztu oraz tego, w jaki sposób i przez kogo jest ono konstruowane. Przekład jest zawsze kosztem ponoszonym przez język dominujący, nawet jeśli jest rzekomo darmowy - w sytuacji, w której koszty zostaną dyskretnie przesunięte na użytkowników języków rzadziej używanych, zniknie on jedynie z pola widzenia rodzimych użytkowników lingua franca. W kontekście ukrywania niezbędnej do wykonania pracy (w przypadku tłumaczeń - pracy językowej) i kosztów należy zwrócić uwagę na szerokie zjawisko dezintermediacji - pojawienie się bankowości elektronicznej sprawiło, że pracę kasjera-pośrednika możemy wykonać sami, jednak jedynie pod warunkiem, że posiadamy komputer z dostępem do Internetu, i choć przyzwyczailiśmy się już do narracji udogodnień, to w praktyce koszty, które do tej pory ponosił bank - koszty sprzętu, oprogramowania, opłacenie pracownika, a wreszcie poświęcony czas - zostały zamaskowane lub przerzucone na nas samych. W przypadku systemów tłumaczenia maszynowego online, dostępnych wszystkim użytkownikom Internetu, dezintermediacja nabiera zupełnie nowego wymiaru, łączącego się z postrzeganiem samej czynności przekładu. Automatyczne tłumaczenie uzyskane przez kliknięcie ikonki „Przetłumacz" lub opcji „Przetłumacz na...” w przeglądarce Google Chrome, to coś więcej niż zwykłe stuknięcie w klawisz - to zmiana paradygmatu. Niezależnie od jakości uzyskanego w ten sposób wyniku, proces dezintermediacji, zachodzący w danym momencie, wprowadza oto wizję tłumaczenia ,jako formy natychmiastowego transferu językowego" przypominającego zautomatyzowane procesy przetwarzania danych [Cronin 2016: 61-64].

Podsumowując, przyszłością tłumaczenia komputerowego są bez wątpienia coraz bardziej zaawansowane sieci neuronowe, które będą uczyć się języków na podstawie analizy ogromnych ilości danych w celu poznania rządzących nimi prawidłowości. Można przy tym założyć, że przynajmniej w najbliższym czasie domeną tłumaczenia komputerowego pozostaną teksty silnie skonwencjalizowane, np. teksty techniczne (zadowalające efekty wykorzystywania języków kontrolowanych w ich przypadku pozwala sądzić, że jakość przekładu będzie rosnąć przy jednoczesnym obniżaniu ceny) oraz tłumaczenia skierowane do mało wymagających użytkowników, którym wystarczy zrozumienie ogólnego sensu wypowiedzi źródłowej. Niezwykle ciekawie przedstawia się perspektywa łączenia technologii tłumaczenia komputerowego z technologiami rozpoznawania znaków i tekstów, a także przetwarzaniem mowy - zdaje się być ona zwiastunem upowszechniania się idei rozszerzonej rzeczywistości, a w konsekwencji być może nawet swego rodzaju cyborgizacji ludzkości. Choć w chwili obecnej rozwój tłumaczenia komputerowego na pierwszy rzut 
oka nie niesie za sobą żadnych zagrożeń, to z perspektywy profesjonalnego tłumacza zauważalna już dziś jest dezintermediacja, która zapewne będzie się pogłębiać wraz z rozwojem technologii. Najbardziej aktualną kwestią mogącą wywołać dyskomfort jest postępująca zmiana sposobu postrzegania zawodu tłumacza przez pryzmat zautomatyzowanego procesu tłumaczenia pisemnego - w powszechnej świadomości konstytuuje się przekonanie, że rola człowieka sprowadza się do zaledwie postedycji tłumaczenia wykonanego przez maszynę, co może prowadzić do umniejszania znaczenia wymagającej ogromu pracy i umiejętności sztuki przekładu.

\section{Bibliografia}

Austermühl F. 2014. Electronic Tools for Translators, Abingdon and New York: Routledge.

Bartnicka M., Hofmann-Delbor A. 2017. Programiści i ttumacze. Wprowadzenie do lokalizacji oprogramowania, Gliwice: Helion.

Bogucki Ł. 2009. Ttumaczenie wspomagane komputerowo, Warszawa: Wydawnictwo Naukowe PWN.

Bojar O., Buck C., Federmann C., Haddow B., Koehn P., Leveling J., Monz C., Pecina P., Post M., Saint-Amand H., Soricut R., Specia L., Tamchyna A. 2014. Findings of the 2014 Workshop on Statistical Machine Translation, źródło elektroniczne: http:/ / statmt.org/ wmt14/pdf/W14-3302.pdf (dostęp: 4.11.2017).

Cronin M. 2016. Przekład w epoce cyfrowej, Kraków: Wydawnictwo Uniwersytetu Jagiellońskiego.

Ferguson N. 2016. Adaptive MT for SDL Trados Studio 2017: a self-learning machine translation engine - SDL Trados Blog, źródło elektroniczne: https://blog.sdltrados.com/adapti vemt-sdl-trados-studio-2017-transformational-mt-technology (dostęp: 30.10.2017).

Hutchins J. 2006. The first public demonstration of machine translation: the Georgetown-IBM system, 7thJanuary 1954,źródłoelektroniczne:http:/ / www.hutchinsweb.me.uk/GU-IBM -2005.pdf (dostęp: 30.10.2017).

Popović M. 2017. Comparing Language Related Issues for NMT and PBMT between German and English, źródło elektroniczne: https://ufal.mff.cuni.cz/pbml/108/art-popovic. pdf (dostęp: 5.11.2017).

Rehm G., Uszkoreit H. 2012. The Polish Language in the Digital Age, Berlin-Heidelberg: Springer-Verlag.

Thurmair G. 2009. Comparing different architectures of hybrid Machine Translation systems, Ontario: International Association for Machine Translation.

Wu, Y., Schuster M., Chen Z., Le Q. V., Norouzi M., Macherey W., Krikun M., Cao Y., Gao Q., Macherey K., Klingner J., Shah A., Johnson M., Liu X., Kaiser Ł., Gouws S., Kato Y. 2016. Google's Neural Machine Translation System: Bridging the Gap between Human and Machine Translation, źródło elektroniczne: https://arxiv.org/pdf/1609.08144.pdf (dostęp: 5.11.2017).

Yandex. Как победить морников: Яндекс запустил гибридную систему перевода - Блог Яндекса. 2017. źródło elektroniczne: https://yandex.ru/blog/company/kak-pobedit -mornikov-yandeks-zapustil-gibridnuyu-sistemu-perevoda (dostęp: 30.10.2017). 
